\title{
Role of formula and rice varieties on the characteristics of rice-based spring roll wrappers
}

\author{
*Widjajaseputra, A.I. \\ Faculty of Agricultural Technology-Widya Mandala Catholic University Surabaya, Dinoyo 42-44 Surabaya \\ 60265, East Java, Indonesia
}

\author{
Article history: \\ Received: 21 August 2020 \\ Received in revised form: 29 \\ August 2020 \\ Accepted: 6 September 2020 \\ Available Online: 12 \\ September 2020
}

\section{Keywords:}

Formula,

Rice varieties,

Rice-based,

Spring roll wrapper,

Egg white albumin,

Tapioca starch

DOI:

https://doi.org/10.26656/fr.2017.4(6).456

\begin{abstract}
The used formula in food processing could affect the product characteristics, including on rice-based spring roll wrappers. This research was aimed to find out an appropriate formula to get cohesive and firm mass by using four kinds of rice-based formulas on two different varieties of rice. Mentik Wangi and Ciherang varieties were used as the two preferred local rice varieties. The research used the randomized block design of nested experiment. The ingredients used for each formulation were rice flour and water $\left(\mathrm{F}_{1}\right)$; rice flour, tapioca starch and water $\left(\mathrm{F}_{2}\right)$; rice flour, egg white albumin and water $\left(\mathrm{F}_{3}\right)$ and rice flour, tapioca starch, egg white albumin and water $\left(\mathrm{F}_{4}\right)$. The weakness of rice flour is the difficulty to form cohesive mass and firm network because of its lack of gluten. The combination of egg white albumin and tapioca starch along with sufficient mechanical energy intended to carry out viscosity increasing and create an appropriate texture. The study indicated that best formula was $\mathrm{F}_{4}$ from both of Mentik Wangi and Ciherang varieties which produced cohesive and firm mass. There was no significant difference between the two rice varieties $(\mathrm{P}>0.05)$. The characteristics of rice-based spring roll wrapper from Mentik Wangi and Ciherang varieties were; firmness: $0.5532 \pm 0.0051 \mathrm{~N}$ and $0.8131 \pm 0.0057 \mathrm{~N}$; elongation at break: $15.98 \pm 0.47 \%$ and $16.28 \pm 0.29 \%$ and moisture retention capacity: $38.29 \pm 0.12 \%$ and $42.60 \pm 0.29 \%$ respectively.
\end{abstract}

\section{Introduction}

Spring roll wrappers are made from wheat flour in Indonesia, but most of the wheat flour must be imported from abroad, so this research studied the product characteristics by using rice flour to substitute wheat flour in spring roll wrapper processing. There are several local of rice varieties that are available and preferred by common Indonesian society, among them, there are namely Mentik Wangi and Ciherang varieties. The base consideration of using rice flour to substitute wheat flour in fresh spring roll wrapper formula was its availability. Rice flour is the most commonly used in gluten-free formulations due to it is available, easily digested, colorless and hypoallergenic (Kim et al., 2015). Rice has relatively poor technological properties in interacting and developing a cohesive network (Charoenthaikij et al., 2018).

Non-cohesive mass is not able to hold water well, so the use of egg whites in rice-based spring roll wrappers formula expected to increase cohesiveness with stronger protein-water interactions by heat-induced gel during heating of the batter. Egg white consisted of water $(88 \%)$, protein $(11 \%)$, minerals, trace of lipids and carbohydrates in around 1\% (Abeyrathne et al., 2013). Most of egg white proteins are globular proteins such as ovalbumin and conalbumin which require pre-heating to induce partial denaturation or opening of polypeptide chains so that three-dimensional matrix of protein gels will form a firm and cohesive mass. These characteristics will give benefit to rice-based spring roll wrapper because it can retain more water and fat in the added filling. The addition of liquid albumin to parboiled rice (15 g/100 g rice flour) create starch molecules were surrounded homogeneously by a protein network which stabilized mostly by hydrophobic interactions and disulfide bonds (Marti et al., 2015). Egg white albumin begins to coagulate at $62^{\circ} \mathrm{C}$ and becomes very firm at temperatures higher than $70^{\circ} \mathrm{C}$ (Mukprasirt et al., 2000). These characteristics of liquid albumin can provide stabile structure during cooking condition on $72^{\circ} \mathrm{C}$ for 4 mins.

Tapioca starch is the most commonly used hydrocolloid thickener because it is relatively cheap, 
abundant and it did not give any noticeable taste. Tapioca starch produces an elastic mass during gelatinization, yielding a higher cohesion. It was also reported that crumb cohesiveness increased along with increasing of starch content in the formulation containing cassava starch (Onyango et al., 2010). There was a certain ratio amount of egg white to tapioca starch, which have used in different gluten-free products such as (7:1) in developed gluten-free bread (Breshears and Crowe, 2013). Dacey and O'Connor (2014) reported that the composition of rice flour in ready-to-bake gluten-free pizza dough formulation is less than about $12 \%$ by weight to prevent a gritty baked pizza crust, meanwhile tapioca starch may be present in an amount from $15 \%$ to $25 \%$ by weight to get a smoother texture pizza dough. The usage of tapioca starch in the recipe may join the effect of egg white to improve the product structure as a binder (Han et al., 2019). Widjajaseputra et al. (2011) reported that tapioca, along with egg whites at the optimum ratio of rice flour to water, contributed significantly to the cohesiveness of rice-based spring-roll wrapper.

The fresh spring roll wrapper making process was based on Widjajaseputra (2010). Heating was held until the batter temperature on $72 \pm 1^{\circ} \mathrm{C}$ for 4 mins. The batter temperature and duration of heating have provided partially gelatinization for rice starch and complete of gelatinization for tapioca starch, so this cooking condition will produce the flexible, firm and cohesive product. Hasjim et al. (2013) reported gelatinization temperature range of rice flour was from $72.3^{\circ} \mathrm{C}$ to $82.8^{\circ}$ C.

This research aimed to find out the best formula of rice-based spring roll wrapper which produced cohesive mass and firm enough by using four kinds of rice-based formulas of two different varieties of rice, namely Mentik Wangi and Ciherang. Characteristics of the desired rice-based spring roll wrapper should be flexible, firm and cohesive enough but it could be rolled easily.

\section{Materials and methods}

\subsection{Materials}

Rice flour from Mentik Wangi and Ciherang varieties was produced by grinding dry rice grains (without soaking) and sifted with 80 mesh sieve size. The rice flours were air-dried to get a uniform moisture level (about $5 \%$ ) at $35^{\circ} \mathrm{C}$ for $9-10 \mathrm{hrs}$ in drying oven (Venticell MMM Medcenter Einrichtungen GmbH). Leghorn chicken eggs were obtained from a local shop in Surabaya-East Java-Indonesia. The chemical composition of the rice flours and tapioca starch is shown in Table 1.
Table 1. Chemical composition of rice flours of varieties and tapioca starch ( $\%$ wet basis $)^{\mathrm{a}}$

\begin{tabular}{lccc}
\hline \multirow{2}{*}{ Component } & \multicolumn{2}{c}{ Rice Flours } & Tapioca \\
\cline { 2 - 3 } & $\begin{array}{c}\text { Mentik Wangi } \\
\text { Variety }\end{array}$ & $\begin{array}{c}\text { Ciherang } \\
\text { Variety }\end{array}$ & starch \\
\hline Water & 3.31 & 5.14 & 5 \\
Protein & 10.09 & 11.19 & 2.9 \\
Ash & 0.47 & 0.37 & 1.9 \\
Fat & 1.22 & 0.81 & 0.4 \\
Reducing Sugar & 0.22 & 0.36 & - \\
Starch & 80.38 & 80.26 & 86.5 \\
Amylose Level & $20.14 \pm 0.46^{\mathrm{b}}$ & $23.0^{\mathrm{c}}$ & $17.7^{\mathrm{d}}$ \\
\hline
\end{tabular}

${ }^{\mathrm{a}}$ Widjajaseputra (2010), ${ }^{\mathrm{b}}$ Anugrahati et al. (2015), ${ }^{\mathrm{c}}$ Mardiah et al. (2016), ${ }^{\mathrm{d}}$ Matsunaga et al. (2003)

\subsection{Rice-based spring roll wrapper preparation}

A total of four formulas of rice-based spring roll batters were prepared using ingredients composition in Table 2 and homogenized using a magnetic stirrer with a speed of $100 \mathrm{rpm}$ for 2 mins. Then, the batter was poured into a $10 \mathrm{~cm}$ diameter Teflon coated frying pan and heated until the temperature reached $72 \pm 1^{\circ} \mathrm{C}$ on an automatic stirrer hot plate set at $125^{\circ} \mathrm{C}$ for 4 mins. The spring rolls wrappers were measured for firmness, moisture retention capacity and elongation at break analysis.

Table 2. Formula of rice-based spring roll wrapper

\begin{tabular}{lcccc}
\hline \multirow{2}{*}{ Ingredients $(\%)^{\text {a }}$} & \multicolumn{4}{c}{ Formula } \\
\cline { 2 - 5 } & $\mathrm{F}_{1}$ & $\mathrm{~F}_{2}$ & $\mathrm{~F}_{3}$ & $\mathrm{~F}_{4}$ \\
\hline Rice flour $^{\mathrm{b}}$ & 27 & 23 & 27 & 23 \\
Tapioca starch $^{\mathrm{c}}$ & - & 4 & - & 4 \\
Egg white $^{\mathrm{c}}$ & - & - & 27 & 27 \\
Pure water & 73 & 73 & 46 & 46 \\
\hline
\end{tabular}

${ }^{a}$ All ingredient percentages are given in weight/weight $\%$

${ }^{\mathrm{b}}$ Rice flour from Mentik Wangi variety or Ciherang variety

${ }^{c}$ Water content of egg white $88 \%$

\subsection{Viscosity analysis}

Viscosity analysis was performed on the batter. About $300 \mathrm{~mL}$ of batter was placed in a $500 \mathrm{~mL}$ of beaker for viscosity measurement. The batter was heated until $72 \pm 1^{\circ} \mathrm{C}$ and held for 4 mins. The viscosity was determined at $35 \pm 1^{\circ} \mathrm{C}$ using the Brookfield Viscometer Helipath Stand LVDVE model. A total of four measurements were performed for each sample.

\subsection{Firmness analysis}

Firmness of the rice-based spring roll wrapper was measured using the Texture Profile Analyzer (TPA)TA.XT type with $5 \mathrm{~kg}$ load cell. Samples in $20 \mathrm{~mm}$ x 20 $\mathrm{mm}$ size were put at the center of aluminium plate under the $4 \mathrm{~mm}$ diameter cylindrical probe. The sample was 
passed by pre-test speed $1 \mathrm{~mm} / \mathrm{s}$, test speed $2 \mathrm{~mm} / \mathrm{s}$ and post-test speed $2 \mathrm{~mm} / \mathrm{s}$. The distance from sample to probe was $40 \mathrm{~mm}$. For this analysis, four replicates were performed.

\subsection{Elongation at break measurement $(\% E)$}

Samples were prepared with $1 \mathrm{~cm} \times 6 \mathrm{~cm}$ in size of the strip and measured by autograph (Shimadzu type AG $-10 \mathrm{TE}$ with capacity $5 \mathrm{kN}$ or $500 \mathrm{kgf}$ ) for elongation of break analysis. A total of four replicates were performed.

\subsection{Moisture retention capacity}

The moisture retention capacity of the samples was determined via the Gravimetric method (AOAC, 2010). Samples were heated at $105^{\circ} \mathrm{C}$ for $5 \mathrm{hrs}$ in a drying oven. The dried spring rolls wrapper was divided into nine segments and for each segment, the moisture retention capacity was calculated using the following equation:

Moisture retention capacity $=[$ Initial weight $(\mathrm{g})-$ sample weight after heating (g)] / Initial weight (g) x 100\%.

\subsection{Experimental design and statistical analysis}

The research used the randomized block design of nested experiment. Four levels of formulation $\left(F_{1}, F_{2}, F_{3}\right.$, and $\mathrm{F}_{4}$ ) were nested within each of two of rice varieties (Mentik Wangi and Ciherang). The experiment was carried out with four replications. Data were analyzed using the SAS (Statistical Analysis System) version 9.3 to perform ANOVA followed by a Least Significant Difference test $(\mathrm{P} \leq 0.05)$ for means comparison.

\section{Results and discussion}

\subsection{Batter viscosity}

Based on the analysis of variance, there was no significant difference between the two of rice varieties on batter viscosity. But there were significant differences between formulas within varieties on the batter viscosity $(\mathrm{P} \leq 0.05)$. Figure 1 shows that in both rice varieties, $\mathrm{F}_{4}$ had the highest viscosity compared to other formulas. The increase of viscosity was due to the formation of hydrophobic interaction and hydrogen bonds between proteins and starch molecules during hydration and gelatinization processes. The starch granules swell during heating and increase the viscosity before the damage of its molecular structure. The role of rice proteins, especially glutelin $(77-78 \%$ of total rice proteins) and ovalbumin from egg whites that form heatsetting gels during heating contributed to the increase of viscosity. The batter viscosities from Ciherang variety tend to be higher than batters from Mentik Wangi. These phenomena could be due to higher amylose and protein contents of Ciherang variety which were $23 \%$ and
$11.19 \%$ respectively than Mentik Wangi which were $20.14 \%$ and $10.09 \%$ respectively (Table 1 ). The higher amylose and protein contents of Ciherang variety seemed to also affect the gelation capacity which will increase the viscosity of the batter during heating. Jeong et al. (2017) reported that the viscosity of lower amylose content will start to increase at lower temperatures, implying lower gelatinization temperatures. It may be due the lower amylose starch structure was easier disrupted. Likitwattanasade and Hongsprabhas (2010) reported that protein and amylose fractions contributed their significance in the RVA (Rapid Visco Analyser) pasting profiles at separated phases. Further, it was reported that the amylose content influenced the final viscosity more that protein content of rice cultivar. Even the results suggested that rice proteins play a significant role in pasting by encasing the starch granules, restricting their swelling and increasing the shear resistance during cooking. Zhang et al. (2011) also reported that the increase of starch amylose content resulted in the increase of flour peak viscosity.

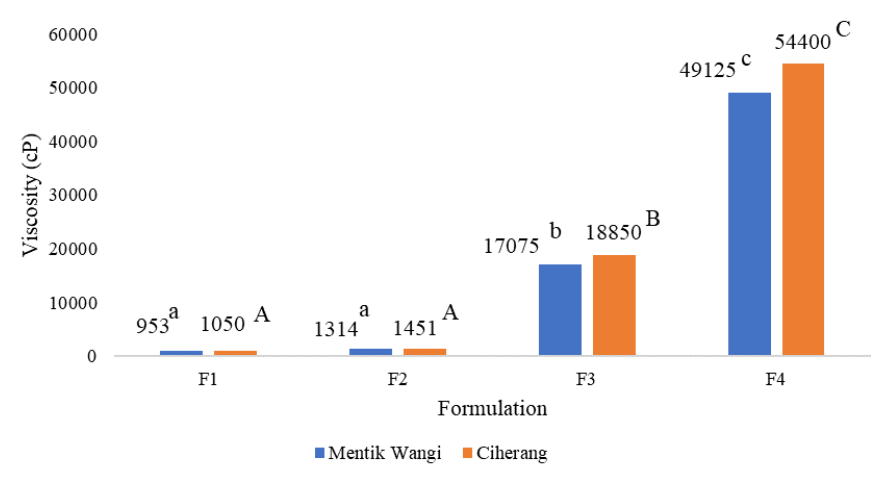

Figure 1. Viscosity of rice-based spring roll wrapper at different formulas and rice varieties. Different letters above bars indicate statistically significant difference $(\mathrm{P}<0.05)$.

\subsection{Firmness}

Different formulas have a significant effect on the firmness of the rice-based spring roll wrappers $(\mathrm{P} \leq 0.05)$ as shown in Figure 2. Although there was no significant effect on the firmness between the two of the varieties, $F_{1}$ had lowest firmness among both of the two varieties, Mentik Wangi and Ciherang, because this formula consisted of rice flour and water only in 27:73 weight ratio. $F_{2}$ had tapioca starch in $4 \%$ total weight, so tapioca starch gave an increasing firmness, but the formed mass was still non cohesive. The increased firmness was due to the leached amylose in the batter during heating with at $72^{\circ} \mathrm{C}$ and held for 4 mins. $F_{3}$ has liquid egg white albumin in the ratio 1:1 to the rice flour without tapioca starch and the firmness value was higher than $F_{1}$ and $F_{2}$ because of the effect of heat which induced gel forming of egg white albumin. When egg white albumin is heated, the hydrophobic groups for cross-link formation 
by intermolecular hydrogen bonding and hydrophobic interaction will form to stabilize the gel network and strengthen the gel matrix. As a gel matrix strengthened, the product will be firmer.

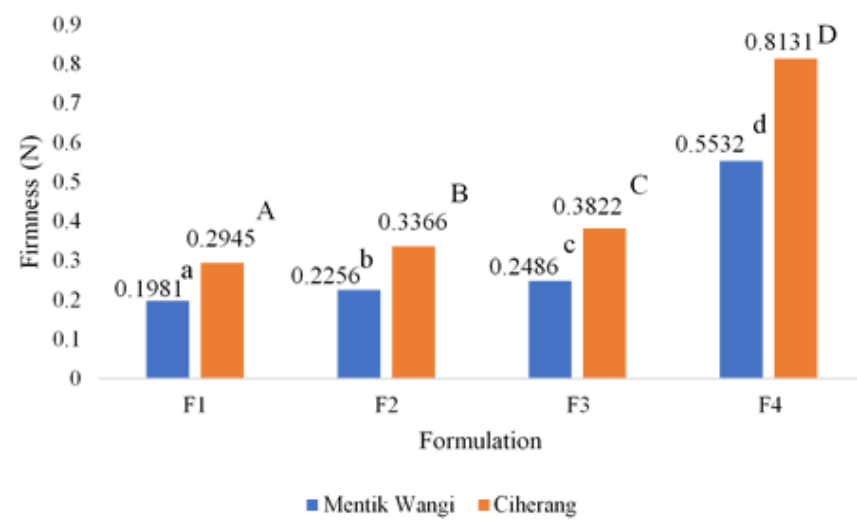

Figure 2. Firmness of rice-based spring roll wrapper at different formulas and rice varieties. Different letters above bars indicate statistically significant difference $(\mathrm{P}<0.05)$.

Marti et al. (2014) reported that the addition of $15 \%$ liquid albumin to rice pasta gave a significant textural and appearance improvement of rice-based pasta with low cooking loss and firmer. The usage of high eggproteins in gluten-free pasta made from parboiled rice flour improved the cooking quality because the proteins may form a denser network during cooking. It was also reported that there was increase of tensile strength, firmness, and extensibility of rice noodle with the increase of egg white proportion in amount up to $50 \%$ $(\mathrm{w} / \mathrm{w})$, while the extensibility increased with the addition of egg white in the amount of $10-30 \%$ and it decreased on higher egg white proportions in an amount of $40 \%$ and 50\% (Kerdsrilek and Garnjanagoonchorn, 2014). This phenomenon was due to the formation of a rigid and fragile gel. The egg white proportion used in this study was $27 \%(\mathrm{w} / \mathrm{w})$ which revealed that proper using of egg white in amount of lower than $30 \%$ produced desired firmness of rice-based spring roll wrapper.

The firmness of all investigated products of $F_{1}, F_{2}$, $F_{3}$, and $F_{4}$ formulas from Ciherang variety tend to be higher than that of Mentik Wangi variety. Again, this phenomenon can be linked to the high content of amylose and protein of Ciherang variety (Table 1) which is supported by Ahmed et al. (2016) who reported there is a positive correlation between the amylose and protein content with the firmness of noodle strands. Jeong et al. (2017) stated that paste made from the higher amylose level $(26 \%)$ showed higher storage moduli than it was made from the lower amylose content, thus amylose level seemed to have positive contribution in firmer structure formation.

The addition of tapioca starch influenced the elastic property of rice-based foods, meanwhile rice starch showed higher dynamic moduli value compared to tapioca starch. It was due to its smaller granule size (Sun and Yoo, 2015). Further, it was reported that gel strength values of rice starch (RS) and tapioca starch (TS) blends tend to increase with an increase of amount ratio of TS $(0.30 \mathrm{~N}-0.64 \mathrm{~N})$. These values were higher than the gel strength of rice starch and tapioca starch itself, $0.17 \pm 0.01$ $\mathrm{N}$ and $0.16 \pm 0.01 \mathrm{~N}$ respectively. Tapioca starch, which origin from tuber roots has longer chains of glucose unit polymers than rice starch and hence, it will improve product texture by increasing the elasticity and water holding capacity in an optimal amount. The water holding capacity tends to increase with the gel strength which will improve the strength of rice-based spring roll wrapper.

\subsection{Elongation at break}

The elongation at break of rice-based spring roll wrapper from Mentik Wangi and Ciherang varieties was $15.98 \pm 0.47 \%$ and $16.28 \pm 0.29 \%$, respectively, as shown in Table 3. The elongation at break of rice-based spring roll wrapper of Ciherang variety was higher than Mentik Wangi variety due to the higher protein and amylose contents of Ciherang variety than Mentik Wangi. Both protein and amylose are gel formers which affect the firmness and elasticity and contribute to the increase of elongation at break at an optimal level. This characteristic will influence the flexibility of the wrapper. The wrapper will be easier to roll. The previous research showed that the higher amylose level than $28 \%$ tended to decrease elongation at break from $14.52 \%$ to $10.96 \%$ at the level of amylose content $40 \%$ (Widjajaseputra et al., 2010). It was due to the longer distance of molecular components and weakening of intermolecular bonds. Consequently, more water will be trapped in the gel system, causing it to be brittle. Tam et al. (2004) also reported about the optimal amylose level

Table 3. Elongation at break (\%) of rice-based spring roll wrapper of formulas nested in Mentik Wangi and Ciherang varieties

\begin{tabular}{ccc}
\hline Rice variety & Formulation & Elongation at break*(\%) \\
\hline \multirow{4}{*}{ Mentik } & $\mathrm{F}_{1}$ & - \\
& $\mathrm{F}_{2}$ & - \\
& $\mathrm{F}_{3}$ & - \\
& $\mathrm{F}_{4}$ & $15.98 \pm 0.47$ \\
\hline \multirow{4}{*}{ Ciherang } & $\mathrm{F}_{1}$ & - \\
& $\mathrm{F}_{2}$ & - \\
& $\mathrm{F}_{3}$ & - \\
& $\mathrm{F}_{4}$ & $16.28 \pm 0.29$ \\
\hline
\end{tabular}

*The elongation at break (mean $\pm \mathrm{SD} \%$ ) could not be measured on $F_{1}, F_{2}$ and $F_{3}$ because those formulas were not able to form a cohesive mass as shown in Figure 4. 
in normal maize starches with an amylose content of about $28 \%$ were successfully used to produce bihon-type noodle, but amylose level with 40.0-60.8\% and 0.2-3.8\% failed to form the noodles. Jeong et al. (2017) also stated that paste made from a mixture of zein and high amylose rice flours at $26 \%$ level showed greater elastic properties than a mixture of zein and rice flours with $12 \%$ and $19 \%$ amylose level.

\subsection{Moisture retention capacity}

Statistical analysis revealed that rice varieties were not statistically significant based on the moisture retention capacity $(\mathrm{P}>0.05)$. Otherwise, there was a significant difference $(\mathrm{P} \leq 0.05)$ among formulas within varieties. $\mathrm{F}_{4}$ of Mentik Wangi and Ciherang varieties retained more water compared to other formulas as shown in Figure 3. This phenomenon was due to gel system formation of $\mathrm{F}_{4}$ by the presence of hydrophilic compounds contained in the batters.

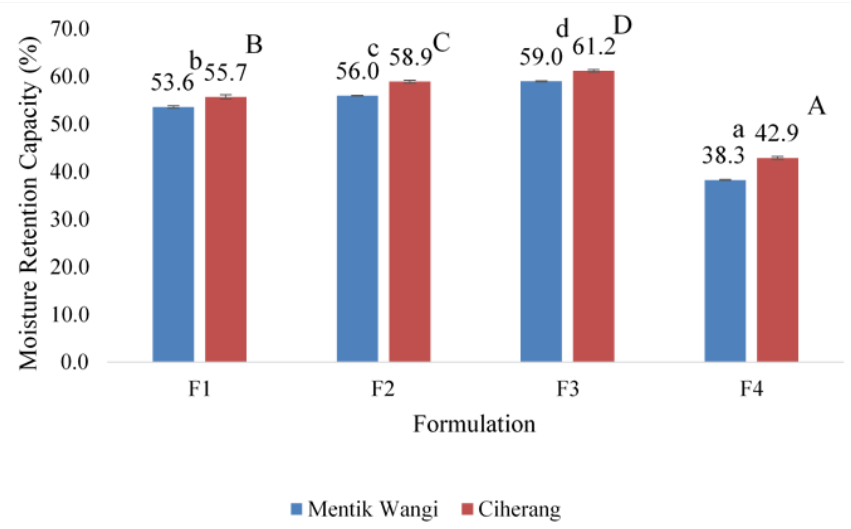

Figure 3. Moisture retention capacity (\%) of rice-based spring roll wrapper at different formulas and rice varieties. Different letters above bars indicate statistically significant difference ( $\mathrm{P}$ $<0.05)$.

In formulas containing egg white albumin, denaturation occurred and underwent coagulation to form heat-induced gel. One important function of the protein in the food system is the gelation. Gelation is the formation of a three-dimensional matrix through hydrogen bonds between proteins and allows immobilization of water in the gel structure. The interaction between starch and protein in food systems increased the gel strength as a result of increased protein matrix density and elastic starch formation (Jamilah et al., 2009). This characteristic determined the binding capacity of the water by the formed gel matrix, as shown in Figure 4. Cohesive mass occurred in the rice-based spring roll wrapper of both two rice varieties of F4. It was due to the combined effect of egg white albumin and tapioca starch in the formula. The instability of the gel matrix caused low water holding capacity which occurred in a non-cohesive mass. The moisture content reflected the ability of a product to hold entrapped water during processing. The firmness reflects the gel system stability, which depends on the type and amount of the constituent compounds. The firmness of the gel system also reflects the inter-molecular and intra-molecular bonds that occur in the presence of heating (Widjajaseputra, 2012). The addition of Egg White Protein (EWP) increased Water Holding Capacity (WHC) of duck sausage which was prepared using tapioca starch. The WHC of duck sausages was used EWP $(60.00 \%)$ and without EWP (57.80\%) respectively (Muthia et al., 2012). It was also related to the binding properties of both egg white albumin and tapioca starch to other food components of rice-based foods. The amount of evaporated water reflects on the ability to keep the water in the gel matrix system during heating or cooking. During heating or cooking, the technological properties of rice-based food product will be improved through the gelatinization of starch and coagulation of proteins. A firmer texture, low stickiness and high shear resistance to optimally reduce the cooking loss is often preferred (Gomez and Sciarini, 2015).

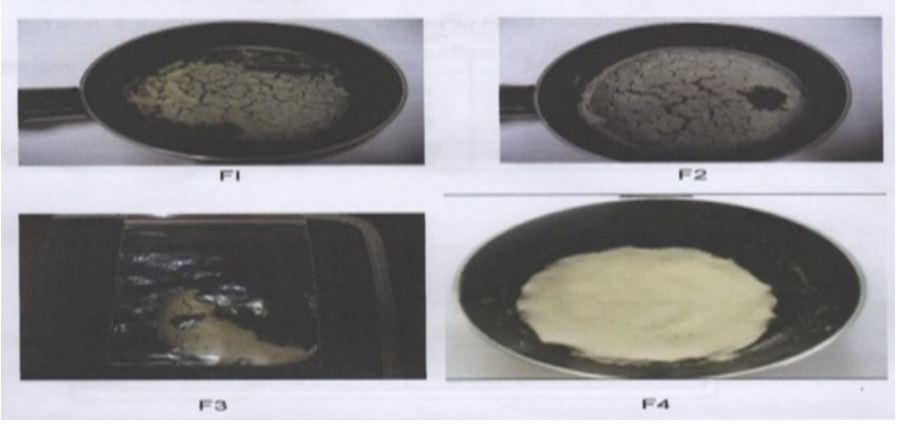

Figure 4. Photograph of several formulas of rice-based spring roll wrappers. Source: Widjajaseputra (2010)

\section{Conclusion}

The structure of rice-based spring roll wrapper depends on the interaction between the components of the material such as starch-water, protein-water, and starch-protein interactions. All the interactions will determine the viscosity of the batter, firmness of products and moisture retention capacity. Based on the results of this study, it can be concluded that the formula and components in each variety influenced the characteristics of rice-based spring roll wrapper especially from standpoints of firmness, elongation at break and moisture retention capacity. There was no significant difference between the two rice varieties $(\mathrm{P}>$ 0.05 ) as both varieties have similar intermediate-amylose rice content (20-25\%). The basis of rice variety selection is the availability and consumer preference, so further investigation is needed with other basic considerations, such as different amylose classification and usage of broken rice for by-products utilization. The best- 
observed formula was $\mathrm{F}_{4}$ from both of Mentik Wangi and Ciherang varieties which produced cohesive and firm mass. The characteristics of rice-based spring roll wrapper from Mentik Wangi and Ciherang varieties have firmness: $0.5532 \pm 0.0051 \mathrm{~N}$ and $0.8131 \pm 0.0057 \mathrm{~N}$; elongation at break: $15.67 \pm 0.39 \%$ and $16.28 \pm 0.29 \%$ and moisture retention capacity: $38.29 \pm 0.12 \%$ and $42.60 \pm 0.29 \%$ wet basis, respectively.

\section{Conflict of interest}

The authors declare no conflict of interest.

\section{Acknowledgments}

The author would like to express the gratitude to Widya Mandala Catholic University Surabaya who gave facilities and support to provide the research and to all of my colleagues: Th. Endang Widoeri, MP; Dr Srianta; Dr Paini; Maria Matoetina, MP for all of their support and input that make this paper can be finished.

\section{References}

Abeyrathne, E.D.N.S., Lee, H.Y. and Ahn, D.U. (2013). Egg white protein and their potential use in food processing or as nutraceutical and pharmaceutical agents - a review. Poultry Science, 92(12), 32923299. https://doi.org/10.3382/ps.2013-03391

Ahmed I., Qasi I.M., Li Z. and Ullah J. (2016). Rice Noodles: Materials, Processing and Quality Evaluation. Proceedings of the Pakistan Academy of Sciences: B. Life and Environmental Sciences, 53(3), 215-238.

Anugrahati, N.A., Pranoto, Y., Marsono, Y. and Marseno, D.W. (2015). In vitro digestibility of Indonesian cooked rice treated with the coolingreheating process and coconut milk addition. International Research Journal of Biological Sciences, 4(12), 34-39.

AOAC. (2010). Official Methods of Analysis. Washington, DC, USA: AOAC.

Breshears, K.L. and Crowe, K.M. (2013). Sensory and textural evaluation of gluten-free bread substituted with amaranth and montina ${ }^{\mathrm{TM}}$ flour. Journal of Food Research, 2(4), 1-10. https://doi.org/10.5539/ jfr.v2n4p1

Charoenthaikij, P., Prommin, A., Suratananun, A., Itthisophonkul, T. and Naknaen, P. (2018). Physicochemical properties and sensory quality of gluten-free brown rice pasta enriched with egg white protein. The Journal of King Mokut's University of Technology North Bangkok, 28(3), 627-638. https:// doi.org/10.14416/j.kmutnb.2018.04.004
Dacey, M. and O'Connor, C. (2016). Ready-to-bake gluten-free pizza dough formulation. US20160150798A1. Retrieved from Google Patents website: https://patents.google.com/patent/ US20160150798A1/en

Gomez, M. and Sciarini, L.S. (2015). Gluten-free bakery products and pasta. In Arranz, E., FernandezBanares, F., Rosell, C.M., Rodrigo, L., Pena and A.S. (Eds). Advances in the understanding of glutenrelated pathology and the evolution of gluten-free foods, p. 565-604. Barcelona, Spain: OmniaScience. https://doi.org/10.3926/oms.265

Han, A., Romero, H.M., Nishijima, N., Ichimura, T., Handa, A., Xu, C. and Zhang, Y. (2019). Effect of egg white solids on the rheological properties and bread-making performance of gluten-free batter. Food Hydrocolloids, 87, 287-296. https:// doi.org/10.1016/j.foodhyd.2018.08.022

Hasjim, J., Li, E. and Dhital S. (2013). Milling of rice grains: effects of starch/flour structures on gelatinization and pasting properties. Carbohydrate Polymers, 92(1), 682-690. https://doi.org/10.1016/ j.carbpol.2012.09.023

Jamilah, B., Mohamed, A., Abbas, K.A., Rahman, R.A., Karim, R. and Hashim, D.M. (2009). Protein-starch interaction and their effect on thermal and rheological characteristics of a food system: A review. Journal of Food, Agriculture and Environment, 7(2), 169-174.

Jeong, S., Kim, M., Yoon, M.-R. and Lee, S. (2017). Preparation and characterization of gluten-free sheeted doughs and noodles with zein and rice flour containing different amylose contents. Journal of Cereal Science, 75, 138-142. https:// doi.org/10.1016/j.jcs.2017.03.022

Kerdsrilek, A. and Garnjanagoonchorn, W. (2014). Effect of duck egg white addition on textural properties and microstructure of rice noodles. International Food Research Journal, 21(6), 21552159.

Kim, M., Yun, Y. and Jeong, Y. (2015). Effect of corn, potato, and tapioca starches on the quality of glutenfree rice bread. Food Science and Biotechnology, 24 (3), 913-919. https://doi.org/10.1007/s10068-0150118-8

Likitwattanasade, T. and Hongsprabhas, P. (2010). Effect of storage proteins on pasting properties and microstructure of Thai rice. Food Research International, 43(5), 1402-1409. https:// doi.org/10.1016/j.foodres.2010.04.011

Mardiah Z., Rakhmi A.T., Indrasari S.D. and Kusbiantoro B. (2016). Grain quality evaluation to 
determine consumer preference pattern of rice in Java Island, p. 163-172. Sukamandi-West JavaIndonesia: Indonesian Center for Rice Research (ICRR).

Marti, A., Barbiroli, A., Marengo, M., Fongaro, F., Iametti, S. and Pagani, M.A. (2014). Structuring and Texturing gluten-free pasta: egg albumen or whey proteins. European Food Research and Technology, 238, 217-224. https://doi.org/10.1007/s00217-0132097-4

Matsunaga, K., Kawasaki, S. and Takeda, Y. (2003). Influence of physicochemical properties of starch on crispness of tempura fried batter. Cereal Chemistry, 80(3), 339-345. https://doi.org/10.1094/ CCHEM.2003.80.3.339

Mukprasirt, A., Herald, T.J. and Flores, R.A. (2000). Rheological characterization of rice flour-based batters. Journal of Food Science, 65(7), 1194-1199. https://doi.org/10.1111/j.1365-2621.2000.tb10264.x

Muthia, D., Huda, N. and Ismail, N. (2012). The effect of egg white powder addition with tapioca and sago flours on physicochemical and sensory properties of duck sausage. International Food Research Journal, 19(4), 1415-1421.

Onyango, C., Mutungi, C., Unbenhend, G. and Lindhauer, M.G. (2010). Modification of Gluten-free SorghumBatter and Bread Using Maize, Potato, Cassava or Rice Starch. LWT-Food Science and Technology, 44(3), 681-686. https://doi.org/10.1016/ j.lwt.2010.09.006

Sun, D. and Yoo, B. (2015). Effect of tapioca starch addition on rheological, thermal, and gelling properties of rice starch. LWT-Food Science and Technology, 64(1), 205-211. https://doi.org/10.1016/ j.lwt.2015.05.062

Tam, L.M., Corke, H., Tan, W.T., Li, J. and Collado, L.S. (2004). Production of bihon-type noodles from maize starch differing in amylose content. Cereal Chemistry, 81(4), 475-480. https://doi.org/10.1094/ CCHEM.2004.81.4.475

Widjajaseputra, A.I. (2010). The role of amylose and several processing conditions on characteristics of fresh rice-based spring rolls wrappers. Malang, Indonesia: Brawijaya University, $\mathrm{PhD}$ Thesis.

Widjajaseputra, A.I., Harijono, Yunianta and Estiasih, T. (2010). The role of amylose and tempering time on characteristics of fresh rice-based spring rolls wrappers. Proceedings of 2nd International Conference on Biosciences and Biotechnology. Denpasar-Bali, Indonesia: Udayana University Press -Udayana University

Widjajaseputra, A.I., Harijono, Yunianta and Estiasih, T.
(2011). Effect of flour to water ratio on characteristics of fresh rice-based spring rolls wrappers. Journal of Technology and Food Industry, 22(3), 184-189.

Widjajaseputra, A. (2012). Relation of moisture distribution and texture of rice-based foods-a perspective. International Food Research Journal, 19(3), 1275-1278.

Zhang, S.B., Lu, Q.Y., Yang, H. and Meng, D.D. (2011). Effects of protein content, glutenin-to gliadin ratio, amylose content, and starch damage on textural properties of Chinese fresh white noodles. Cereal Chemistry, 88(3), 296-301. https://doi.org/10.1094/ CCHEM-05-10-0072 